УДК 349.2

DOI https://doi.org/10.32849/2663-5313/2020.4.17

Лілія Амелічева,

канд. юрид. наук, дочент,

дочент кафедри иивільного права і процесу

Донецького національного університету імені Василя Стуса

\title{
ПРАВОВЕ ЗАБЕЗПЕЧЕННЯ ПРОФЕСІЙНОЇ ОСВІТИ І НАВЧАННЯ ПРАЦІВНИКІВ В УМОВАХ КРИЗИ ГІДНОЇ ПРАЦІ ТА «ОЗЕЛЕНЕННЯ» ЕКОНОМІКИ
}

Стаття присвячена проблематииі правового забезпечення професійної освіти і навчання прачівників в умовах кризи гідної прачі та «озеленення» економіки.

Аргументовано, що свогодні модернізачію і реформування професійної освіти інавчання громадян Украйни необхідно здійснювати, переймаючи успішний досвід Європейського Союзу в цвому питанні. Необхідно використовувати єдині Європейські освітні стандарти і кваліфікаиії. Це дозволить розширити простір ринку пращі, полегшить процес пращевлаштування та організацію практичного навчання наших громадян.

Проведений аналіз чинного законодавства у сфері праиі, зайнятості, професійної освіти та навчання дозволяє зробити такі висновки. По-перше, вченим-правознавиям необхідно уніфікувати міжгалузеві базові поняття з метою більш ефективного їх використання у подальшому різними суб'єктами нормотворчості під час розробки нових законодавчих актів у сфері прачі, зайнятості і професійної освіти та навчання, актів учасників сочіального діалогу, локальних документів роботодавиів у зазначеній сфері. По-друге, детальних змін потребує чинний Кодекс законів про прачю України, зокрема Глава ХIV «Пільги для прачівників, які поєднують роботу з навчанням» у зв'язку з реформуванням професійної освіти і навчання в умовах євроінтеграчії та в процесі досягнення гідної прачі та сталого розвитку. Його слід доповнити положеннями про організацію дуальної освіти, формального і неформального професійного навчання прачівників.

Обгрунтовано, що необхідно посилити сочіальний діалог з питань створення «зелених» робочих місиь з гідними умовами пращі з огляду на прагнення Украӥни досягти сталого розвитку і гідної прачі 3 дотриманням приниипів «зеленої економіки». За новими професіями, що належать до «зелених» технологій, необхідно розробити сучасні професійні стандарти на засадах сочіального діалогу. Також слід активніше розроблювати Регіональні иільові програми розвитку професійної освіти і навчання за участю роботодавців, які базуються на реальному попиті у фахівиях, зокрема, в галузях «зеленої економіки», де створюються нові «зелені» робочі місия.

Ключові слова: концепція гідної праці, дуальна освіта, правове регулювання, неформальна професійна освіта, «зелені» робочі місця.

Постановка проблеми. 3 метою забезпечення національних інтересів Україна підтримала глобальну стратегію сталого розвитку, взяла на себе зобов'язання забезпечити стійке зростання економіки екологічно не виснажувальним способом [1], дотримуючись принципів «зеленої» економіки [2, ст. 293] та Програми гідної праці МОП [3].

Сучасний глобальний характер сталого розвитку економіки характеризується стрімкою трансформацією «коричневої» економіки (яка в основному враховує природний капітал виключно як джерело матеріалів і енергетичних ресурсів для виробництва товарів) в «зелену». Сьогодні все більше нових «зелених» робочих місць створюється роботодавцями в таких галузях економіки, як: енергокомплекс, сільське господарство, фармація, медицина, харчова і легка промисловість, транспорт, будівництво та ін. (Необхідно відразу зауважити, що МОП визначає поняття «зелених» робочих місць досить широко - як будь-які робочі місця, що відповідають принципам гідної праці, які сприяють збереженню і якісному відновленню навколишнього середовища, будь то в сільському господарстві, промисловості, сфері послуг або управління [4]).

Незважаючи на позитивні сторони такої трансформації для природи й людства, вона часто призводить до того, що роботодавці, організовуючи нові робочі місця, в тому числі 
«зелені», стикаються 3 повною відсутністю або значною недостатністю у працівників радикально нових напрямів професійного досвіду і знань, навичок і компетентностей [5]. До цих напрямів належать, перш за все, такі, як: спеціалізація з локальних систем енергопостачання (вітряної, сонячної та ін.) екоаналітика у видобувних галузях, архітектура «енергонульових» будинків, сіті-фермерство та ін. Також під час впровадження i застосування прогресивних технологій на виробництві нерідко відчувається недостатня сформованість, особливо у інженерно-технічного складу, сучасних і затребуваних компетенцій, таких як: екологічна обізнаність, системне мислення і творчий потенціал, спрямовані на вирішення проблем 3 потребою винаходів, нововведень у зазначеній сфері з урахуванням специфіки роботи конкретного підприємства [6].

Неефективність правового забезпечення сучасної системи професійної освіти і навчання працівників в Україні є серйозною перешкодою для досягнення соціального та економічного прогресу нашої країни, зокрема для забезпечення гідної праці, розвитку трудового потенціалу та подолання невідповідності між попитом і кваліфікаціями на ринку праці [7].

Аналіз останніх досліджень і публікацій. У науці трудового права проблематика професійної освіти і навчання працівників, незважаючи на іï міжгалузевий характер, завжди активно досліджується, враховуючи людиноцентристський характер цього питання, особливі риси професійної освіти, такі як гнучкість і креативність. Слід відзначити важливі останні дослідження і публікації із цієї тематики.

Так, у науковій праці М. В. Демченко на основі системного підходу здійснювалося комплексне розкриття особливостей правового регулювання підготовки та додаткової професійної освіти працівників на сучасному етапі [8]. У дослідженні О. В. Гаврилюка виявлені проблеми правового регулювання стажування працівників та розроблені пропозиції щодо його подальшого вдосконалення в умовах розбудови ринкової економіки [9]. У науковій праці М. В. Лушнікової й А. М. Лушнікова досконально вивчалася й характеризувалася система професійної освіти і навчання в країнах Західної Європи на базі трьох основних моделей соціального партнерства [10]. Ці вчені зауважували, що сьогодні до організації професійної освіти і навчання кадрів висуваються нові вимоги, продиктовані інтелектуалізацією суспільної праці в XXI столітті [10, с. 46]. Робота С. Б. Серякової присвячена досвіду країн
Західної Свропи з питань правового регулювання додаткової професійної освіти [11]. У науковій праці В. С. Пересунька висвітлювалися гарантії основного галузевого права працівників - права на безкоштовне професійне навчання на виробництві, включаючи і безкоштовне підвищення трудової кваліфікації, досліджувалися деякі причини неефективного забезпечення цих гарантій роботодавцями сьогодні [12]. Дослідження Н. В. Рибак присвячене проблемам правового забезпечення професійного зростання окремих категорій працівників, зокрема слідчих органів внутрішніх справ, у сучасних умовах [13].

Не применшуючи значення праць вказаних вчених трудового права, слід зазначити, що комплексного дослідження проблем правового забезпечення модернізації та реформування пострадянської системи професійної освіти та навчання кадрів у сучасних умовах розвитку України насамперед з урахуванням впровадження в життя концепції гідної праці, сталого розвитку й активного «озеленення» економіки ще не проводилося.

| Метою дослідження $€$ аналіз системи чинного законодавства у сфері праці, зайнятості та професійної освіти і навчання, а також викладення авторського бачення сучасних проблем правового забезпечення професійної освіти і навчання працівників в умовах кризи гідної праці та «озеленення» економіки.

Виклад основного матеріалу. Професійний розвиток працівників як компонента гідної праці є одним із найважливіших чинників забезпечення конкурентоспроможності нашої країни на ринку праці. Проте нечувана швидкість старіння методів управління, теоретичних знань, умінь і практичних навичок, здатність організації до постійного професійного розвитку персоналу призвела до кризи моральних цінностей трудового життя або до кризи гідної праці [14, с. 324]. Так, відповідно до індексу інноваційного розвитку, представленого агентством Bloomberg у 2019 році, Україна значно втратила (20 позицій за один рік) порівняно з 2018 роком і зайняла 48 місце за ефективністю вищої освіти серед 60 країн світу [15; 16].

Шлях вирішення цієї проблеми лише один - прискорення реформування сфери професійної освіти та навчання працівників та інших осіб за допомогою поетапного вдосконалення національного законодавства про працю, зайнятість та освіту на базі міжнародних та європейських стандартів у зазначеній сфері, під впливом партнерства України з Європейським фондом освіти (агентством ЄС, далі - ЄФО) [6] та МОП. 
Отже, підтримавши стратегію сталого розвитку та концепцію гідної праці в умовах євроінтеграції, Україна як ніколи сьогодні потребує прискорення реформування та модернізації професійної освіти та навчання, яке можливе лише за умови удосконалення національного законодавства у сфері праці, зайнятості, професійної освіти і навчання.

Так, у статті 432 Угоди про асоціацію між Україною, з одної сторони, та Європейським Союзом, Свропейським Співтовариством з атомної енергії та їхніми державами членами, з іншої сторони, наша держава як Сторона зобовязується здійснювати заходи, спрямовані на активізацію обміну інформацією, практикою та досвідом, для заохочення більш плідної співпраці в галузі професійнотехнічної освіти та навчання. Метою здійснення таких заходів є: а) розвиток систем професійно-технічної освіти та навчання, подальше підвищення кваліфікації протягом трудової діяльності (життя), що відповідає реаліям у контексті змін на ринку праці; b) створення національних механізмів з метою покращення прозорості та визнання кваліфікацій та компетенцій, використовуючи, коли це можливо, досвід ЄС [2].

У Декларації Свропейської Комісії та Міністрів професійної освіти європейських країн 3 розвитку співробітництва в галузі професійної освіти і навчання в Свропі, прийнятій на засіданні 29-30 листопада 2002 року в Копенгагені, вказується, що розширення Європейського Союзу відкриває нові перспективи і можливості, а також ставить цілий ряд нових завдань і вимог до системи освіти i професійного навчання. Особливе значення тут матиме залучення країн, що вступають до Європейського Союзу, до співпраці у сфері освіти та професійного навчання як рівноправних партнерів із самого початку реалізації майбутніх ініціатив на європейському рівні. У цій Декларації визначено три стратегічні цілі, що закладені в основу такої спільної діяльності: підвищення якості та ефективності систем освіти та професійного навчання в Європейському Союзі, полегшення доступу до освіти та професійного навчання для всіх громадян та відкриття систем освіти та професійного навчання для зовнішнього світу.

У контексті цього дослідження важливо підкреслити сильні сторони сучасної європейської системи професійної освіти та навчання, які може перейняти вітчизняна система професійної освіти та навчання під час їі реформування. До них належить: 1) узгодженість ступенів освіти (плавний перехід від одного до іншого ступеня, наступність змісту освіти як у рамках усього освітнього процесу, так і всередині окремих предметів); 2) приведення змісту підготовки кваліфікованих фахівців за певними напрямами в різних країнах до єдиних європейських освітніх стандартів і кваліфікацій, що розширює простір ринку праці, полегшуе процес працевлаштування та організацію практичного навчання; 3) вільний і усвідомлений вибір професії (спеціальності) i напрями спеціалізації учнів професійних шкіл, коли вони самі вибирають тривалість і рівень освіти; 4) можливість безперервної підготовки і перепідготовки за вибраною професією (спеціальністю) протягом усієі професійної кар'єри; практична спрямованість професійної освіти, велика кількість годин практичного навчання, різноманітність видів практики, тісний зв'язок 3 теоретичним навчанням та ін. [17].

У Розділі 1.3 «Професійна освіта» Дорожньої карти освітніх реформ (2015-2025), розробленої Стратегічною дорадчою групою при МОН України з урахуванням досвіду ЄC, передбачені першочергові заходи щодо реформування системи професійної освіти і навчання, передусім правового характеру, які натепер здебільшого вже реалізовані. Насамперед це стосується розробки необхідних нормативно-правових актів та освітніх стандартів дуальної освіти. Так, натепер вже ухвалений Закон України «Про професійну (професійно-технічну освіту» від 10.02.1998 № 103/98-ВР, схвалена Концепція підготовки фахівців за дуальною формою здобуття освіти від 19 вересня 2018 р. № 660-р. Триває підготовка Регіональних цільових програм розвитку професійної освіти за участю роботодавців, які базуються на реальному попиті у фахівцях (з урахуванням перспектив розвитку національного та регіонального ринків праці) [18]. На жаль, у цій дорожній карті освітніх реформ не передбачено внесення змін до чинного Кодексу законів про працю України, що $є$ основним регулятором трудових відносин, у тому числі і з професійного навчання, перепідготовки працівників.

Отже, в Україні правове забезпечення професійної освіти та навчання громадян здійснюється на основі норм Закону України «Про освіту» від 05.09.2017 № 2145-VIII, Закону України «Про професійну (професійно-технічну) освіту» від 10.02 .1998 № 103/98-ВР, Закону України «Про вищу освіту» від 01.04.2014 № 1556-VII, якими передбачено, що безпосередньо освітні послуги громадянам надаються закладами професійної (професійно-технічної) освіти та закладами вищої освіти. 
Професійна освіта і навчання працівників регулюється положеннями Розділу XIV «Пільги для працівників, які поєднують роботу з навчанням» КЗпП України, в яких передбачається, що для професійної підготовки і підвищення кваліфікації працівників, особливо молоді, роботодавець організує індивідуальне, бригадне, курсове та інше виробниче навчання за рахунок підприємства, організації, установи, а також закріплюються обов'язки роботодавця щодо створення для працівників, які проходять виробниче навчання або навчаються в навчальних закладах, необхідних умов для поєднання роботи і навчання. Слід зауважити, що покладання обов'язку з організації виробничого навчання працівників лише на роботодавця в сучасних умовах глобалізації та «озеленення» економіки, на наш погляд $є$ для нього непомірним тягарем, особливо якщо він належить до розряду малого і середнього бізнесу.

Положення про професійну освіту і навчання в КЗпП України хоча і передбачають багато гарантій для працівників, проте не повністю відповідають задачам модернізації системи професійної освіти і навчання в Україні відповідно до Концепції підготовки фахівців за дуальною формою здобуття освіти від 19.09.2018№ 660-р, Порядку підтвердження результатів неформального професійного навчання осіб за робітничими професіями від 15.05.2013 № 340, а також не відповідають правовій позиції Міністерства соціальної політики України, викладеній у листі від 25.05.17 № 421/0/126-17 «Щодо організації професійного навчання на виробництві».

Також варто зазначити, що в КЗпП України відсутні норми, що розкривають зміст такихбазових понять, як: «дуальненавчання», «неформальне професійне навчання», «формальне професійне навчання» та ін. У КЗпП України не передбачаються положення про порядок підтвердження результатів неформального професійного навчання, а також норми, які закріплюють право роботодавця як соціального партнера на участь у розробці регіональних і цільових програм професійної освіти, які повинні орієнтуватися на реальну потребу у фахівцях на державному, галузевому та регіональному рівні.

Тому норми КЗпП України необхідно переглянути з цих питань, узгодивши їх за змістом із положеннями як вищезазначених нормативно-правових актів, так і інших важливих законів, що регулюють відносини в цій сфері. До цих законів слід віднести:

1) Закон України «Про професійний розвиток працівників» від 12.01.2012 № 4312-VI, у статті 5 якого зазначається розширення кола учасників у сфері професійного розвитку працівників. До них законодавцем віднесено професійні спілки та їх об'єднання, організації роботодавців та їх об'єднання. Спільно 3 органами державної влади ці суб'єкти повинні брати участь у моніторингу ринку праці та прогнозуванні його розвитку, формуванні державного замовлення на підготовку фахівців, у тому числі що стосуються «зелених» технологій. Важливим результатом такого соціального діалогу повинна стати на постійній основі спільна розробка доповнень Національної рамки кваліфікацій новими компетентностями для різних кваліфікаційних рівнів фахівців і розробка програм з потенційного підвищення кваліфікації працівників, зайнятих на нових «зелених» робочих місцях;

2) Закон України «Про формування та розміщення державного замовлення на підготовку фахівців, наукових, науковопедагогічних та робітничих кадрів, підвищення кваліфікації та перепідготовки кадрів» від 20.11.2012 № 5499-VI, норми якого регулюють відносини, які виникають у зв'язку з формуванням і розміщенням державного замовлення на підготовку фахівців, наукових, науково-педагогічних та робітничих кадрів, підвищення кваліфікації та перепідготовку кадрів з урахуванням потреб суспільства і держави, зокрема, коли створюються нові робочі місця у галузях, що активно піддаються «озеленення»;

3) Закон України «Про стимулювання інвестиційної діяльності в пріоритетних галузях економіки 3 метою створення нових робочих місць» від 06.09.2012 № 5205-VI, норми якого спрямовані на створення умов для активізації інвестиційної діяльності шляхом концентрації ресурсів держави на пріоритетних напрямах розвитку економіки 3 метою впровадження енергозберігаючих технологій, створення нових робочих місць;

4) Закон України «Про зайнятість населення» від 05.07.2012 № 5067-VI, положення якого регулюють питання професійного навчання осіб з робітничими професіями, професійного навчання, підготовки і перепідготовки працівників у порядку, передбаченому законодавством, колективним договором і угодами.

Як вже вище зазначалося, розробка цих законів проводилася в процесі партнерства України з ЄФО, який має великий досвід професійної освіти і навчання працівників в умовах «озеленення» економіки за участю сторін соціального діалогу в розвинених країнах [6], вивчення якого слід продовжити в подальших наукових дослідженнях із даної тематики. 


\section{Висновки}

Отже, завершуючи представлене наукове дослідження, слід виснувати таке.

Сьогодні модернізацію і реформування професійної освіти і навчання громадян України необхідно здійснювати, переймаючи успішний досвід Свропейського Союзу в цьому питанні, використовуючи єдині Європейські освітні стандарти і кваліфікації. Це дозволить розширити простір ринку праці, полегшить процес працевлаштування та організацію практичного навчання наших громадян.

Проведений аналіз чинного законодавства у сфері праці, зайнятості, професійної освіти та навчання дозволяє зробити такі висновки. По-перше, необхідно уніфікувати міжгалузеві базові поняття, які вище згадувалися в цій роботі, з метою більш ефективного їх використання різними суб'єктами нормотворчості під час розробки нових законодавчих актів у сфері праці, зайнятості і професійної освіти та навчання, актів учасників соціального діалогу, локальних документів роботодавців у зазначеній сфері. По-друге, потребує детальних змін чинний Кодекс законів про працю України, зокрема Глава XIV «Пільги для працівників, які поєднують роботу з навчанням», у зв'язку із проведенням реформування професійної освіти і навчання в умовах євроінтеграції та в процесі досягнення гідної праці та сталого розвитку. Його слід доповнити положеннями про організацію дуальної освіти, формального і неформального професійного навчання й ін.

Враховуючи прагнення України досягти сталого розвитку і гідної праці, дотримуючись принципів «зеленої економіки», необхідно посилити соціальний діалог з питань створення «зелених» робочих місць 3 гідними умовами праці. За новими професіями, що належать до «зелених» технологій, необхідно розробити сучасні професійні стандарти на засадах соціального діалогу. Також слід активніше розроблювати Регіональні цільові програми розвитку професійної освіти за участю роботодавців, які базуються на реальному попиті у фахівцях (з урахуванням перспектив розвитку національного та регіонального ринків праці), зокрема, і в галузях «зеленої економіки», де створюються нові «зелені» робочі місця.

\section{Список використаних джерел:}

1. Про Цілі сталого розвитку України на період до 2030 року : Указ Президента України від 30 вересня 2019 року № 722/2019 / Верховна Рада України. URL: https://zakon.rada.gov.ua/laws/ show/722/2019 (дата звернення: 12.03.2020).
2. Про ратифікацію Угоди про асоціацію між Україною, з однієї сторони, та Європейським Союзом, Європейським Співтовариством з атомної енергії та їхніми державами-членами, з іншої сторони : Закон України від 16 вересня 2014 року № 1678-18 / Верховна Рада Украӥни. URL: https:/ zakon.rada.gov.ua/laws/show/1678-18 (дата звернення: 12.03.2020).

3. Декларация МОТ о социальной справедливости в целях справедливой глобализации : принята Международной конференцией труда на 97-й сессии, Женева, 10.06.2008. URL: https:// goo-gl.su/O3wZ (дата звернення: 17.03.2020).

4. Зеленые рабочие места: к достойному труду в устойчивом мире с низким содержанием углерода: политические посылы и рекомендации для лиц, принимающих решения : доклад ЮНЕП, MOT, МОР, МКП, Офис ООН в Найроби. $2008.25 \mathrm{c}$.

5. Обучение для зеленого будущего. INFORM. 2012. Вып. № 11. URL: https://goo-gl.su/SOML (дата звернення: 07.03.2020).

6. Анализ системы профессионального образования и обучения в Украине. «Туринский процесс» (2013-2014). Сайт Европейского фонда образования. URL: https://goo-gl.su/mb6hz (дата звернення: 07.03.2020).

7. Соціальні партнери розпочали підготовку до підписання Програми МОП гідної праці для України на 2020-2024 роки. 19.12.2019. Сайт Федерачї роботодавиів Украӥни. URL: https://goo-gl.su/fYyI (дата звернення: 11.03.2020).

8. Демченко М.В. Правовое регулирование подготовки и дополнительного профессионального образования работников : дисс. ... канд. юрид. наук: 12.00.05. Москва, 2019. 199 с.

9. Гаврилюк О.В. Правове регулювання стажування працівників : дис. ... канд. юрид. наук: 12.00.05. Київ, 2019. $191 \mathrm{c.}$

10. Лушникова М.В., Лушников А.М. Право на профессиональное образование и обучение: проблемы реализации в современных условиях. Вестник Ярославского государственного университета им. П.Г. Демидова. Серия «Гуманитарные науки». 2007. № 2. Ст. 46-52.

11. Серякова С. Б. Дополнительное профессиональное образование в России и странах Западной Европы: сопоставительный анализ : монография. Москва : Прометей, 2016. 164 с.

12. Пересунько В.С. Юридичні гарантії при укладенні трудового договору : автореф. дис.. канд. юрид. наук: 12.00.05. Київ, 2002. 20 с.

13. Рибак Н.В. Правове регулювання форм організації праці та професійного зростання слідчих органів внутрішніх справ в сучасних умовах : автореф. дис. ... канд. юрид. наук: 12.00.05 Київ, 2019. 20 с.

14. Даниленко О.А. Професійний розвиток як компонента гідної праці: нові можливості, виклики, механізми реалізації. Професійний розвиток як процес адаптації до мінливих умов занятості (Розд. 5.1.) Гідна праия: імперативи, 
українські реалії, механізми забезпечення : монографія / за заг. ред. А.М. Колот та ін. К.: КНЕУ, $217.500 \mathrm{c}$.

15. The annual Bloomberg Innovation Index 2019. URL: https://goo-gl.su/OIuk

16. The annual Bloomberg Innovation Index 2018.URL: https://goo-gl.su/kXcdP4 (дата звернення: 11.03.2020).
17. Машукова Н.Д. Формирование профессиональных стандартов и их сопряженность с образовательными стандартами. Моква, 2003. C. $49-64$

18. Дорожня карта освітніх реформ (2015-2025). БФ «нститут розвитку освіти». URL: http://mon.gov.ua/content (дата звернення: 11.03.2020).

The article is devoted to the problems of legal support of professional education and training of employees in the context of the crisis of decent work and the "greening" of the economy.

It is argued that today the modernization and reform of professional education and training of Ukrainian citizens should be carried out, taking over the successful experience of the European Union in this matter. It is necessary to use common European educational standards and qualifications. This will expand the space of the labor market, facilitate the process of employment and organize practical training for our citizens.

The analysis of the current legislation in the field of labor, employment, professional education and training allows us to draw the following conclusions. Firstly, legal scholars need to unify the intersectoral basic concepts that were mentioned above in this work, in order to use them more effectively in future rulemaking by various subjects in the development of new legislation in the field of labor, employment and professional education and training, acts of participants in the social dialogue, and local documents of employers in this area. Secondly, the current Labor Code of Ukraine requires fundamental changes, in particular its Chapter $X I V$ "Benefits for employees who combine work with training" in connection with the reform of professional education and training in the context of European integration and in the process of achieving decent work and sustainable development. It should be supplemented with provisions on the organization of dual education, formal and non-formal professional training of employees.

It is proved that it is necessary to strengthen the social dialogue on the creation of "green" jobs with decent working conditions, taking into account the desire of Ukraine to achieve sustainable development and decent work in compliance with the principles of the "green economy". For new professions related to "green" technologies, it is necessary to develop modern professional standards based on the principles of social dialogue. It is also necessary to start developing more actively Regional targeted programs for the development of professional education and training with the participation of employers, which are based on real demand for specialists, in particular in the sectors of the "green economy", where new "green" jobs are created.

Key words: concept of decent work, dual education, legal regulation, non-formal professional education, "green" jobs. 